\section{Sub-State Mobilization in 'High Politics': The Role of Regional and Local Governance in the Implementation of the European Neighbourhood Policy}

\section{Giorgio Oikonomou}

Adjunct Lecturer, Aristotle University of Thessaloniki

Faculty of Economic and Political Sciences; School of Political Sciences

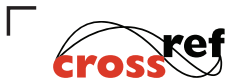

http://dx.doi.org/10.5755/j01.eis.0.12.20869

Subnational mobilization literature has flourished since the mid. 1990s. Regional and local authorities have tried, not always successfully, to utilize alternative channels of representation in the European Union (EU) in different policy areas and with different scope and depth. The policy areas and the degree of subnational mobilization is greatly varied contingent on exogenous -at the EU level- and endogenous - within local and regional organisational capacity- factors. Most commonly, subnational authorities (SNAs) find themselves involved in cohesion policy issues, environmental affairs, and social policy measures, mostly involved in the implementation phase. However, as the EU continuously emphasizes the importance of regional and local authorities in facilitating the European integration process, it has fuelled SNAs' institutional ambitions and expanded their aspirations for participation in new policy areas, even in fields traditionally considered to be exercised -and monopolized-by national authorities, such as foreign policy issues.

This article focuses on the role of subnational institutions in the European Neighbourhood Policy (ENP), a relatively new policy area compared to other established EU policies. In short, the ENP was introduced in 2004 and revised in 2011 and 2015. Its rationale is to bring closer EU countries and their neighbours, so as to work together on issues regarding prosperity, stability and security for all. The ENP constitutes a policy field for subnational authorities that aim to mobilize in the supranational arena. The European Neighbourhood Instrument (ENI - former European Neighbourhood Policy Instrument/ENPI) is the ENP financial tool which provides opportunities for "financial mobilization" to institutional actors by granting funds for implementing programmes. In addition, the European Committee of the Regions (CoR), the official assembly of representatives of local and regional authorities in the EU, stands for another channel for subnational mobilization. Through specific policy initiatives that have been established and promoted by the CoR, namely the Conference of Regional and Local Authorities for the Eastern Partnership (CORLEAP) and the Assembly of Local and Regional elected
EIS 12/2018

Sub-State Mobilization In 'High Politics': The Role of Regional and Local Governance in the Implementation of the European Neighbourhood Policy

Submitted 04/2018 Accepted for publication 09/2018

\section{Abstract}

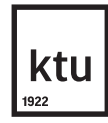

European Integration Studies No. 12 / 2018 pp. 19-31 DOI 10.5755/j01.eis.0.12.20869 
Representatives from the EU and its Mediterranean partners (ARLEM), local and regional institutions have the opportunity to actively participate in the ENP. Moreover, the European Grouping of Territorial Cooperation (EGTC) serves as a distinct policy tool for enhancing territorial development and cooperation, allowing for the engagement of subnational actors from different EU countries -and third countries as well. Drawing on the literature of multi-level governance, it is argued that sub-state entities have managed to expand their institutional role in new policy areas that have been traditionally monopolized by central state authorities. Certain types of subnational mobilization originally found on initiatives proposed and developed by the CoR, the financial instrument of the ENP (ENI) as well as the EGTC are taken into consideration and examined from a comparative perspective.

KEYWORDS: ARLEM; CORLEAP; EGTC; European Neighbourhood Policy; Regional and local authorities.

The European Neighbourhood Policy (ENP) was initially launched in 2003 (Commission of the European Communities, 2003) and developed further in the following year (Commission of the European Communities, 2004). The primer aim of the ENP was to bring closer the European Union (EU) countries and their neighbours, so as to work together on issues regarding the promotion of prosperity, stability and security for all. Based on principles and values such as liberty, democracy, rule of law, universality of and respect for human rights, and good governance, the ENP's scope has broaden after its revisions $(2011,2015)$ taking into account dimensions such as economic development that fosters stabilisation, as well as security and migration issues.

In its core, the policy approach is based on norms/values (democracy; human rights; rule of law) and objectives (stability; security; sustainable development). The ENP is supported by the European Neighbourhood Instrument (ENI) which serves as the financial instrument of the policy'. According to its legal framework that applies for the implementation period 2014-2020² the ENP targets particularly in promoting human rights and fundamental freedoms; equality and the fight against discrimination in all its forms; enhancing sectoral and cross-sectoral cooperation; creating better conditions for the organisation of legal migration and mobility of people; supporting smart, sustainable and inclusive development; good neighbourly relations; sub-regional, regional and European Neighbourhood-wide collaboration as well as cross-border cooperation. In addition, key principles of the ENP are differentiation, partnership and co-financing. The dimension of differentiation is related with the different need(s) of the partner country(-ies) and the commitment to implementing reform objectives and promoting democracy as well; the level of partnership between the EU and the partner country(-ies) and the co-financing of the programmes facilitate also the objectives of the ENP. With regard to the geographic dimension of the ENP, the policy applies in countries that are located in the East (6 countries) and the South (10 countries) of the EU.

Furthermore, the ENP allows for subnational mobilization through EU institutions such as the Committee of the Regions (CoR). In fact, the CoR has launched two policy initiatives with the aim to support the implementation of the ENP. Firstly, the Conference of Regional and Local Authorities for the Eastern Partnership (CORLEAP) deals with countries of the Eastern borders of the EU; its members are the EU and the six member countries of the Eastern Partnership (EaP): Armenia, Azerbaijan, Belarus, Georgia, Moldova, and Ukraine. The EaP, according to the European Commission and the High Representative of the EU for foreign affairs and security policy, is a joint initiative of the EU and the six aforementioned countries and is based on bilateral and multilateral initiatives. The bilateral component aims to promote relations between the EU and each

1 The ENI is utilized by the European External Action Service (EEAS) as a financial tool for political coordination, consistency and effectiveness of the EU's external action (Council Decision 2010/427/EU of 26 July 2010 establishing the organisation and functioning of the European External Action Service - OJ L 201, 3.8.2010, p. 30).

2 Regulation (EU) No 232/2014 of the European Parliament and of the Council, OJ L 77. 
eastern partner country, while the multilateral dimension serves mostly as a platform for political dialogue and exchange of ideas and knowledge on various policy fields: good governance, energy issues, security and economic integration. (European Commission and High Representative of the European Union for Foreign Affairs and Security Policy, 2015a, p. 2). Ordinary meetings are taking place so as to promote dialogue and facilitate the aims of the EaP.

On the south of the EU, the Assembly of Local and Regional elected Representatives from the EU and its Mediterranean partners (ARLEM) is comprised of the EU and 15 countries geographically located around the Mediterranean (Egypt; Turkey; Algeria; Morocco; Syria-currently suspended; Tunisia; Albania; Bosnia and Herzegovina; Israel; Jordan; Lebanon; Mauritania; Palestinian Authority; Monaco; Montenegro). It serves as a political forum that allows elected representatives from the three shores of the Mediterranean Sea to represent their institutions, to maintain and promote political dialogue as well as facilitate interregional cooperation in the area. ARLEM has an observer status with the parliamentary assembly of the Union for the Mediterranean (UfM). The UfM is a regional organization and was formerly known as the "Barcelona Process" (Xenakis, 1999) which initiated in the mid 1990s but with rather marginal -in effect- results. The initiative was restarted in 2008 establishing the UfM, with the aim to contributing to the Euro-Mediterranean political dialogue as well as promoting economic integration across 15 neighbours of the EU to its southern borders (North Africa, the Middle East and the Balkans region) ${ }^{3}$. Along with the $28 \mathrm{EU}$ member states, members of the UfM are also the 15 Southern Mediterranean countries: Albania, Algeria, Bosnia and Herzegovina, Egypt, Israel, Jordan, Lebanon, Mauritania, Monaco, Montenegro, Morocco, Palestine, Syria (currently suspended), Tunisia and Turkey ${ }^{4}$. The UfM represents an opportunity to make institutional relations more functional by launching specific subnational programmes which cope with issues related to economy, environment, energy, migration, education and social affairs as well 5 .

Apart from the two initiatives of the CoR that serve as a political platform and a forum for promoting local democracy and inter-institutional cooperation, as well as for exchanging knowledge and good practices, subnational authorities have the opportunity to participate in another policy instrument, the European Grouping of Territorial Cooperation (EGTC). The EGTC is an institutional platform which facilitates cross-border, interregional as well as transnational cooperation, policy diffusion and exchange of knowledge between its members, thus promoting deeper European integration. Its members can be institutions located in an EU country or outside its territory, allowing thus for the promotion of more close cooperation between institutional actors from the EU and outside its borders.

The aforementioned policy tools, that is the two initiatives held by the CoR (CORLEAP; ARLEM) and the EGTC platform allow subnational authorities to actively participate in the supranational arena, thus, expanding their cooperation with institutional actors located outside their national borders. Consequently, this situation shifts the boundaries and alters the traditional role of local and regional governance from focusing mostly on domestic politics to engaging in international affairs.

The central hypothesis of the paper is that local and regional authorities can play an important role in the implementation phase of the ENP. Opportunities for mobilization are provided through the CoR, thus allowing for the involvement of SNAs in a new policy area. The research question deals with the examination of the policy tools that allow the CoR to actively involve in the field of the ENP and effectively participate in the implementation of the policy. Theoretical framework

3 European External Action Service (2016). http://eueuropaeeas.fpfis. slb.ec.europa.eu:8084/generic-warning-system-taxonomy/404/329/union-mediterranean-ufm_en (accessed: April 2018). Libya holds the status of observer.

4 Ibid.

5 Ibid. 
is principally based on the multi-level governance (MLG) concept. The analysis draws upon the comparative approach of the access points of SNAs to contribute to the ENP. The assessment is made by appraising the impact of local and regional institutions on the implementation of the ENP. Thus, the purpose of this paper is to examine the role of the regional and local authorities in the implementation of the ENP. Drawing on the premise of multi-level governance theoretical conceptualization (Hooghe and Marks, 2001) it is argued that the CoR plays a critical role in the implementation phase of the ENP. The paper also suggests that the EGTC can constitute an additional policy tool that can help realizing the objectives of the ENP.

Methodologically, the paper utilizes empirical evidence from the Euro-Mediterranean Regional and Local Assembly (ARLEM) and its relations with the Union for the Mediterranean (UFM) as well as the Conference of the Regional and Local Authorities for the Eastern Partnership (CORLEAP) to underpin the interplay and the increased role as well of the sub-state authorities represented by the CoR in the policy field of the EU external relations. In both cases, which are compared and contrasted, the impact of the CoR serving as a political platform for discussing and exchanging ideas, in conjunction with its members' capacity to provide assistance to respective authorities from third countries when they deal with EU projects or to facilitate policy transfer and diffusion, i.e. through best practices, allow for the implementation of the core objectives of the ENP. The paper also argues that the EGTC facilitates the ENP objectives, by functioning as a platform for subnational collaboration.

The paper is organized as follows: the next section takes into account theoretical considerations and reviews the relevant literature. Part three presents opportunities for sub-state mobilization through the European Neighbourhood Policy and part four discusses the available access points of SNAs to the ENP from a comparative perspective. Finally, section five provides (tentative) conclusions and offers ideas for future research.

Theoretical considerations
In the early 1990s the multi-level governance (MLG) approach appeared in the literature of EU studies by the seminal work of $G$. Marks (1992). Other academic scholars as well discussed the concept (Hooghe \& Marks, 2001; Bache \& Flinders, 2005; Bache, 2008) and developed it further by proposing certain MLG typologies on the basis of the sharing of authority between different administrative levels (Hooghe and Marks, 2003). Others argued about its potential for becoming a fully-fledged theory (Piattoni, 2009) despite the drawbacks. MLG research dimensions have been summarized and new have been added regarding the use of the concept (Stephenson, 2013).

MLG functions as a precondition for subnational mobilization. According to MLG proponents, the EU policy making process has ceased to be monopolized by national governments and is rather shared by other actors as well (Hooghe \& Marks, 2001, pp. 3-4), at least in some policy fields, stages and to some extent, mostly in the critical phase of policy implementation. Respectively, multi-level interweaving and collaboration between actors from different administrative levels takes place (Hooghe, 1996, p. 17). The multi-level polity setting of the EU allows regional and local institutions to search for opportunities offered in the supranational arena and take advantage of them, such as utilizing financial resources or influencing EU institutions (Hooghe, 1995). By the same token, the EGTC platform allows for multi-level cooperation and interweaving between institutions even from different constitutional regimes.

Subnational mobilization literature discusses the motives, aims, strategies and channels of local and regional representation in Brussels (Hooghe \& Marks, 1996; Marks et al., 1996; Jeffery, 1996; Marks et al., 2002; Tatham, 2008; Tatham, 2010). More recently, the phenomenon of "paradiplomacy" which stands for the international activities of subnational actors has been proposed as a new research agenda (Tatham, 2013; Tatham \& Thau, 2014). 
It has been argued that SNAs and/or their associations mobilize in the EU arena in order to search for funds ("financial mobilization") or for posing influence on EU institutions ("regulative mobilization") (Callanan \& Tatham, 2014). Along these two generic types of mobilization can be also taken into consideration the "cooperative" type of mobilization which aims to promote cooperation and build partnerships among actors from different levels of authority across the European territory and outside of it as well. The principal motive is the collaboration between public authorities in various policy fields, as well as the exchange of knowledge, good practices and expertise. An additional motive can be also the search for funding projects. Respectively, the cooperative type of mobilization overlaps with the financial one. The ECTC falls within this category of subnational mobilization as it provides the necessary multi-level institutional setting for promoting collaboration and synergies among its members, as well as facilitating the search for funds, particularly for those members which lack the necessary administrative capacity (Spinaci \& Vara-Arribas, 2009; De Sousa, 2013; Engl, 2016; Nadalutti, 2013). Since subnational actors from third countries outside the EU may become members in an EGTC, this can substantially serve the objectives of the ENP by, for instance, fostering democratic values and norms through the close cooperation between EU actors and their counterparts from third-countries.

In other words, subnational mobilization allows for the participation of local and regional institutions in policy processes that are unfolded in multi-level institutional environments. The CoR's platforms which have been developed and are linearly related to the ENP (CORLEAP; ARLEM) as well as the EGTC serve the idea of collaboration between SNAs and contribute to the realization of the objectives of the ENP.

The ENP focuses on EU neighbouring countries that are located in two major geographical areas: in the East and the South of the EU ${ }^{6}$. Respectively, the Eastern Partnership, the Southern Neighbourhood, the Neighbourhood-wide cooperation and the cross border cooperation serve as four major policy mechanisms that allow for the implementation of the ENP through operational programmes ${ }^{7}$. During the period 2007-2013 the policy was financially backed by the European Neighbourhood and Partnership Instrument (ENPI) which was replaced by the European Neighbourhood Instrument (ENI) for the period 2014-2020. The majority of the programmes funded by the ENI are based on bilateral cooperation between the EU and neighbouring partner countries. Other types of programmes include multi-country programmes and cross-border cooperation programmes which address cooperation between one or more Member-States of the EU and one or more partner countries (and/or the Russian Federation).

A particular trait of the aforementioned four policy mechanisms of the ENP and the types of the programmes that can be financially supported and implemented is that they all provide significant opportunities for the regional and local authorities to substantially participate in the implementation of the ENP through their official representative body, the Committee of the Regions (CoR). According to a report (CoR (2016) there are five separate areas where SNAs develop -to some extend- forms of collaboration. The first area is related with cross-border programs and donor-driven where there are examples of good practices and "bottom-up" cooperation (i.e in Ukraine, Moldova, Lebanon, and to some extent in Jordan). The second area is related with economic development where the role of SNAs in local economy is linked with the degree of de-

6 With regard to the ENP and the challenges of the policy field, see: Bicchi, 2014; Börzel \& van Hüllen, 2014; Börzel et al., 2015; Edwards, 2008; Freyburg et al., 2009; Gänzle, 2009; Lavenex, 2008; Lavenex \& Schimmelfennig, 2011; Lavenex \& Schimmelfennig, 2009; Noutcheva, 2015; Sasse, 2008; Tömmel, 2013; Zaiotti, 2007.

7 Regulation (EU) No 232/2014 ibid.

8 Regulation (EU) 232/2014, ibid., article 6.
The policy field: opportunities for sub-state mobilization with in the European Neighbourhood Policy 
centralization. The higher the local authority the greater the capacity for SNAs to impact on local economy and vice versa. For instance, in Belarus, Azerbaijan, Egypt, and Algeria subnational institutions lack authority for local development, but in general, SNAs try to do as much within their competencies. The third area is funding. According to the report, the issue of low administrative capacity at the local level stands for a critical factor when it comes for applying for EU funding; however, in the field of environment and energy there are SNAs that cooperate (CoR 2016, p. 2). Finally, regarding the last two areas, that association agreements and migration issues, there is little evidence that SNAs may substantially contribute (ibid.).

Apart from the aforementioned areas that the SNAs may develop forms of institutional cooperation and involve to specific policy fields, the CoR stands for a principal channel allowing for the fostering of international aspirations of local and regional authorities across the EU and beyond its borders. Respectively, the CoR has created two political forums, one for the eastern borders of the EU and one for its southern neighbourhood.

The Conference of local and regional authorities of the Eastern Partnership (CORLEAP) represents the first platform that provides opportunity for subnational mobilization, being directly linked with the ENP. The CORLEAP initiative focuses on the eastern borders of the EU and was set up in 2011 by the CoR, as a joint body of local and regional institutions from the EU and the EaP countries? It serves as a forum for political dialogue and discussion, while promotes the impact SNAs may have on the EaP area, i.e. on issues of local democracy, stability, or by establishing and enhancing political, economic, social and cultural links in the subnational level. In other words, CORLEAP is a territorial cooperation platform helping strengthen local and regional self-government and autonomy in the EaP countries. It consists of 36 members $(18$ members from the CoR and 18 for the EaP member countries). The Council of Europe through the Congress of Local and Regional Authorities of Europe retains observer status within CORLEAP. For the period 2016-2017, the main areas of interest of the CORLEAP platform were: decentralisation and public administration reform, transferring of good practices in the field of public administration and economic development, territorial cooperation ${ }^{10}$. The main objectives of the CORLEAP are linked with the coordination of the representation of SNAs within the EaP; the effective delivering of the ENP and the capacity building at the local and regional level of the EaP countries ${ }^{11}$. Regarding the everyday functioning of the CORLEAP, on the one hand the CoR, through the platform, is the natural contact point for the EU institutions, whereas local and regional associations and unions from the EaP members serve as contact points for CORLEAP in their countries ${ }^{12}$, allowing for the collection and diffusion of information between its members. Regarding the decision-making process, each EaP member country has three seats, while the EU seats are distributed according to CoR's political composition (practically are divided between its -currently- five political groups). The Bureau ${ }^{13}$ of the CORLEAP is held responsible for monitoring the platform's activities and for delivering reports and resolutions. The meetings of the CORLEAP are organized in an annual basis ${ }^{14}$.

Furthermore, the CoR has set up another political platform, the Euro-Mediterranean Regional and Local Assembly (ARLEM) in 2010 so as to cope with the southern neighbourhood of the EU. According to the CoR, the ARLEM is the EU's political assembly of local and regional political representatives, and stands for the territorial dimension within the UfM, allowing elected

9 https://cor.europa.eu/en/our-work/Pages/CORLEAP.aspx (accessed: April 2018).

10 ibid.

11 ibid.

12 ibid.

13 The Bureau consists of 12 members, six from the CoR and six from the partner countries (ibid.).

14 https://cor.europa.eu/en/our-work/Pages/CORLEAP.aspx (accessed: April 2018). 
representatives from states around the Mediterranean Sea to participate in a common political platform and promote dialogue and interregional cooperation as well. The ARLEM consists of 80 members, all representatives of the $43 \mathrm{UfM}$ member states. Its membership is divided up equally between the 15 Mediterranean partners ${ }^{15}$ and the EU through the CoR. The Assembly is comprised of 40 members from the Mediterranean partners and 40 members from the EU (32 CoR members and 8 members from European associations of local and regional institutions engaged in and promoting the Euro-Mediterranean collaboration ${ }^{16}$. ARLEM's core aims are the facilitation of political dialogue and interregional cooperation, the fostering of local democracy, the promotion of decentralised cooperation and regional integration in the Mediterranean area, and the exchange and diffusion of knowledge and expertise among its members ${ }^{17}$. In addition, the Assembly is institutionally related with the European External Action Service (EEAS), the European Commission, the European Parliament, and the European Economic and Social Committee $^{18}$. It also has observer status with the parliamentary assembly of the UfM ${ }^{19}$. Similarly with the CORLEAP, the Congress of Local and Regional Authorities of Europe has observer status within the ARLEM. The Assembly holds annual plenary sessions were action plans for every country, activity reports, and recommendations are proposed and adopted ${ }^{20}$. The Bureau of the ARLEM plans the strategy of the platform. ARLEM is chaired by a joint presidency, representing the Mediterranean partners and the EU (through the CoR) ${ }^{21}$. In addition, the Commission for Sustainable Territorial Development of the ARLEM presents reports on various policy issues such as: decentralisation, sustainable development in urban areas, cultural cooperation, the information society, migration and integration, small and medium-sized enterprises, trade, water management, waste management, (solar) energy, transport etc ${ }^{22}$.

Along with the main platforms for international cooperation within the ENP, the CoR has been a key player in the establishment of another, autonomous platform for territorial cooperation, the EGTC (Nadalutti, 2013). The EGTC portrays an explicit multi-level institutional body that allows for the participation of actors from different governmental/administrative levels. Local, regional and national authorities as well can take advantage of the opportunity structure of the EGTC and mobilize beyond the national borders for developing institutional cooperation and extensive networking and interweaving within the territorial platform by sharing motives and pursuing common aims, exchanging good practices and implementing projects in various policy fields. The EGTC has own legal personality and its main aim is the facilitation of cross-border, interregional and/or transnational cooperation between its members, aiming at promoting economic, social and territorial cohesion in the EU. Since the new Regulation has entered into force ${ }^{23}$ national, regional or local authorities, or bodies or public undertakings from third countries may become members of an EGTC, thus, providing an additional opportunity for authorities outside the EU and serving as an official tool that can support the fulfillment of the targets of the ENP. The platform is governed by a convention which defines the tasks in accordance with the legal framework (EU

15 Egypt (5); Turkey (5); Algeria (4); Morocco (4); Syria (3*); Tunisia (3); Albania (2); Bosnia and Herzegovina (2); Israel (2); Jordan (2); Lebanon (2); Mauritania (2); Palestinian Authority (2); Monaco (1); Montenegro (1). Syria is currenlty suspended due to the political situation. Number in parenteses indicate the allocation of seats for each country within the ARLEM. Source: cor.europa.eu/en/activities/arlem/Pages/arlem.aspx (accessed: April 2018).

16 cor.europa.eu/en/activities/arlem/Pages/arlem.aspx (accessed: April 2018).

17 lbid.

18 lbid.

19 Ibid.

20 Ibid.

21 Ibid.

22 Ibid.

23 Regulation (EU) 1302/2013, OJ L 347. 
Regulations and the national law of the country that the EGTC is seated). The EGTC may implement projects along a wide variety of policy fields and can get additional EU funding as well. In fact, European Structural and Investment Funds provide a critical financial source supporting the implementation of projects by the EGTCs; for instance, in 2017 Erasmus+, Horizon 2020, and Europe for Citizens among other EU programmes co-funded projects coordinated by EGTCs (Committee of the Regions, 2018, p. 111). A potential that the EGTCs can fulfill is the submission of project proposal for financial support in the ENI, the financial instrument of the ENP. In that respect, the EGTCs may take advantage not only from traditional structural funding but also from new EU financial instruments. This will allow for the implementation of the ENP objectives in a more explicit and direct way in comparison to the cooperation and exchange of knowledge that may take place within the members of an EGTC.

Figure one summarizes the potential of SNAs with regard to their opportunities for mobilization in the field of the ENP. Local and regional authorities can mobilize either for financial (ENI) or cooperative reasons (through the CoR and/or the EGTC). With regard to the EGTC and the CoR's initiatives, the established direct links of CORLEAP and the ARLEM with the EaP member countries and the UfM respectively serve as critical institutional policy tools that provide opportunities for subnational mobilization and active participation of SNAs in the implementation of the ENP.

Figure 1

Opportunities for subnational mobilization through the ENP

\section{Discussion}

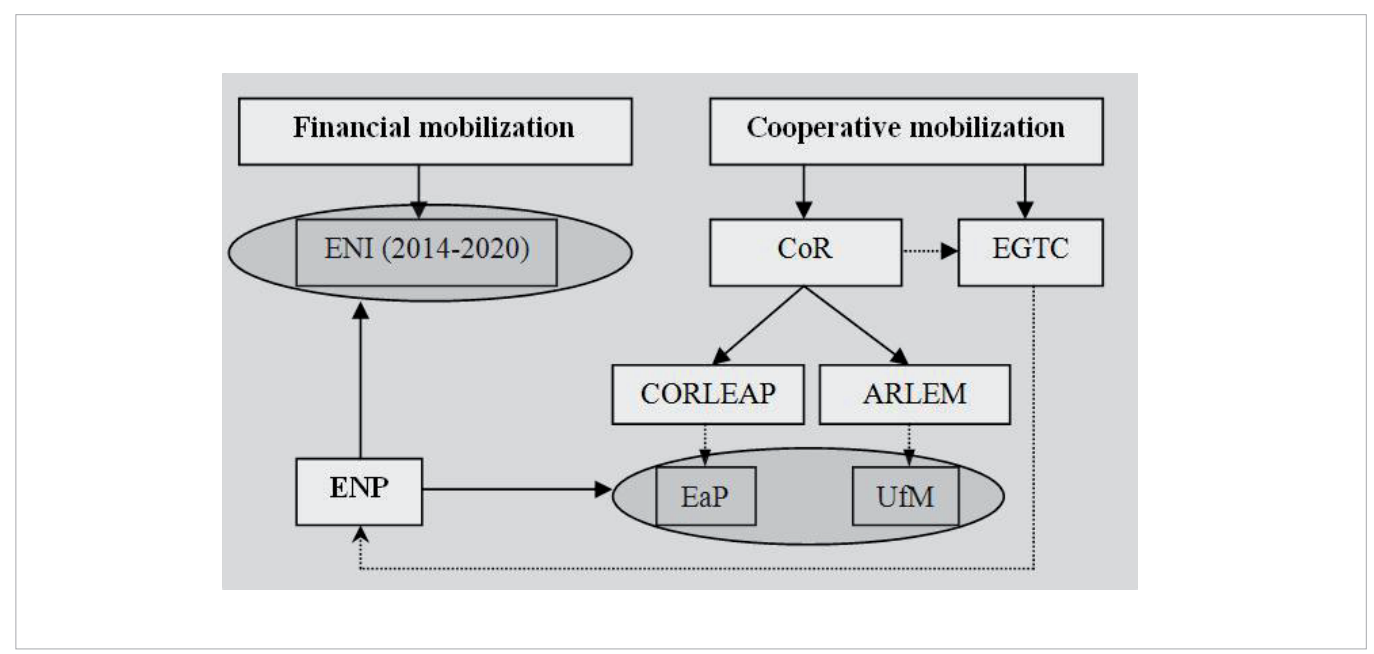

Through bilateral, multi-country and cross-border cooperation programmes the ENP addresses cooperation among the EU and the 16 partner countries. Subnational authorities can play a crucial role particularly during the implementation phase of the ENP. The CoR provides two major institutional forums for political dialogue and cooperation between SNAs that serve as opportunities for subnational cooperative mobilization; in addition the EGTC may stand for an alternative key-player in terms of facilitating direct communication and cooperation within its members as well as acting as project coordinator and beneficiary institution in cases of implementing EU co-funded projects.

With regard to the implementation of the ENP for the programming period 2014-2020 the ENI provides in total EUR 15,4 billions ${ }^{24}$. There are two multiannual allocations, for first four years and the remaining three years respectively. Bilateral programmes receive up to $80 \%$ of the total budget of the ENI, multi-country programmes receive up to 35\%, and cross-border cooperation up to $5 \%$. The policy areas that are financially supported cover issues such as human rights and good governance; sustainable development; mobility and migration; natural resources; agricul-

24 Regulation (EU) No 232/2014, ibid. 
ture; transport and infrastructure; education and training; energy, mobility of persons, goods and capital ${ }^{25}$. It is estimated that for the cross-border cooperation dimension of the ENPI 2007-2013 programme there were found 729 actors; the amount of funding reached $205 \mathrm{~m}$. euro $(183 \mathrm{~m}$. was the ENPI contribution); the average amount of money spent in projects was $2.1 \mathrm{~m}$. euro (min.:429 thousand euro; max: $5 \mathrm{~m}$. euro). In total 95 projects (4.76\% from the 1994 proposals in total) were implemented by SNAs as major coordinators.

The three distinct platforms of institutional cooperation, that is CORLEAP, ARLEM and EGTC, fall mostly within the cooperative type of mobilization as they mostly stand for opportunity structures for political dialogue, cooperation, transferring of knowledge and expertise. Both the ARLEM, part of the governance system of the Union for the Mediterranean, and the CORLEAP "provide operational dynamics and an integrated territorial dimension to the neighbourhood policy"26. In addition, the EGTC may allow for the financial type of subnational mobilization when it submits project proposal in the EU structural and investment funds (potentially in the ENI as well) and acts as a beneficiary on account of its members ${ }^{27}$. The participation of SNAs in an EGTC results in the more effective tackling of resource constraints' problems, such as adequate funding or skilled human capital, a situation that the weaker subnational entities face more often and is recorded particularly in SNAs based on partner countries of the ENP.

Regarding the potential of the EGTC as a policy instrument that could actually serve the objectives of the ENP, it should be mentioned that in 2017 four EGTCs had members from non-EU countries. These were Tisza EGTC, EUCOR The European Campus, Interregional Alliance for the Rhine-Alpine Corridor EGTC and Amphictyony (Committee of the Regions, 2018, p. 106). One illustrative example of member outside the EU is the city of Ramallah (Palestinian Authority) that participates in the EGTC "Amphictyony", a network of twinned cities and areas of the Mediterranean, which is seated in Greece with 39 members $^{28}$ from Greece, Cyprus, Italy, France, and Albania (ibid.). By the end of 2017, 68 EGTCs had been established. However, for the time being the number of authorities from EU neighbouring countries that have joined an EGTC is limited.

Table 1 summarizes the main characteristics of the three distinct institutional channels for subnational mobilization. CORLEAP and ARLEM are settled in the core of the CoR's policy for institutional involment in the ENP. The EGTC serves as an additional tool providing a new and alternative way of promoting subnational cooperation across the EU and neighobouring countries. The objective of stability outside the EU boarder is quite ambitious (i.e. the existence of political tensions), however, there are opportunities for international cooperation even for SNAs, with the aim to promote democracy and good governance.

It has been argued that the ENP has created an institutional framework for advancing cooperation between the EU and neighbouring countries despite the fact that major challenges such as the quality of democracy or the issue of political and economic stability still exist, thus creating obstacles for genuine cooperation (Zajaczkowski, 2017). On the other hand, "the development of legislation in line with EU rules, the implementation of EU best practice, the requirements of the EU single market and EU standards for mobility and border management" have been given particular attention on account of EU institutions (European Commission and High Representative of the European Union for Foreign Affairs and Security Policy, 2015b, p. 15). Though challenges will

25 Ibid.

26 https://portal.cor.europa.eu/mlgcharter/Pages/European-Neighbourhood-Policy-and-Decentralised-Cooperation. aspx (accessed: April 2018).

27 For an overview of the EU funds available for SNAs from the Southern and Eastern Mediterranean Countries: CoR (2012).

$28 \ln 2012$ 
continue to exist (i.e. migratory flows) SNAs may contribute significantly to the fulfillment of the purposes of the ENP. Local and regional authorities play a crucial role in promoting and enhancing democracy (Committee of the Regions, 2013) even outside of the EU borders. According to the CoR (2013), SNAs have gradually become important players in the enlargement process and in foreign policy in general. The added value of their participation is found on examples of multilevel governance and "city diplomacy" during the implementation phase of the ENP both in its Mediterranean dimension and in the Eastern Partnership as well (Committee of the Regions, 2013).

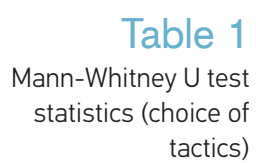

Conclusions

\begin{tabular}{|c|c|c|c|}
\hline & CORLEAP & ARLEM & EGTC \\
\hline $\begin{array}{l}\text { Geographic } \\
\text { area covered }\end{array}$ & $\begin{array}{l}\text { EU; } 6 \text { EaP countries: } \\
\text { Armenia; Azerbaijan; } \\
\text { Belarus; Georgia; } \\
\text { Moldova; Ukraine }\end{array}$ & $\begin{array}{l}\text { EU; } 15 \text { Mediterranean } \\
\text { countries: Egypt; Turkey; } \\
\text { Algeria; Morocco; Syria*; } \\
\text { Tunisia; Albania; Bosnia } \\
\text { and Herzegovina; Israel; } \\
\text { Jordan; Lebanon; Maurita- } \\
\text { nia; Palestinian Authority; } \\
\text { Monaco; Montenegro } \\
\text { (All members are repre- } \\
\text { sentatives of regional and } \\
\text { local bodies of the } 43 \text { UfM } \\
\text { member states**) }\end{array}$ & $\begin{array}{l}\text { Mostly EU countries (and } \\
\text { third countries as well } \\
\text { since 2013). }\end{array}$ \\
\hline Members & $\begin{array}{l}36 \text { ( } 18 \text { from the CoR; } 18 \\
\text { from EaP countries) }\end{array}$ & $\begin{array}{l}80 \text { ( } 40 \text { from the Mediter- } \\
\text { ranean partners; } 40 \text { from } \\
\text { the EU: } 32 \text { from the CoR+8 } \\
\text { from local associations) }\end{array}$ & $\begin{array}{l}\text { SNAs and other au- } \\
\text { thorities may apply for } \\
\text { membership. }\end{array}$ \\
\hline $\begin{array}{l}\text { Type of } \\
\text { mobilization }\end{array}$ & Cooperative & Cooperative & Cooperative/Financial \\
\hline Main objectives & $\begin{array}{l}\text { Local democracy and the } \\
\text { rule of law; stability and } \\
\text { economic development; } \\
\text { cooperation; support for } \\
\text { civil society; increased } \\
\text { mobility of people; energy } \\
\text { security; providing funds } \\
\text { for projects copying with } \\
\text { inequality. }\end{array}$ & $\begin{array}{l}\text { Provide a territorial } \\
\text { dimension to the UfM; } \\
\text { fostering local democracy, } \\
\text { multi-level governance and } \\
\text { decentralised cooperation; } \\
\text { encourage North-South } \\
\text { and South-South dialogue } \\
\text { between SNAs; promote } \\
\text { the exchange of best } \\
\text { practice, knowledge and } \\
\text { expertise; promote region- } \\
\text { al integration and territorial } \\
\text { cohesion. }\end{array}$ & $\begin{array}{l}\text { Financial mobilization, } \\
\text { transferring of knowledge } \\
\text { and expertise, promoting } \\
\text { cooperation }\end{array}$ \\
\hline Means & $\begin{array}{l}\text { Activity reports, action } \\
\text { plans, meetings }\end{array}$ & $\begin{array}{l}\text { Every year: activity report, } \\
\text { action plan, recommenda- } \\
\text { tions and thematic com- } \\
\text { mission reports; multiple } \\
\text { meetings within the year }\end{array}$ & $\begin{array}{l}\text { Coordination; meetings, } \\
\text { seminars, indirect con- } \\
\text { tacts between members, } \\
\text { project implementation } \\
\text { co-funded by the EU }\end{array}$ \\
\hline
\end{tabular}

Source: http:// cor.europa.eu/en/activities/corleap/Pages/corleap.aspx (assessed: April 2018);

http:// cor.europa.eu/en/activities/arlem/Pages/arlem.aspx (assessed: April 2018); own elaboration.

*Currently suspended

The EU stands for an external catalyst for change in 16 of its Eastern and Southern neighbours by developing differentiated bilateral approaches for political, economic and cultural reasons. The role of the sub-state authorities in the implementation of the ENP is crucial: both the Eastern Partnership as well as the Southern Neighbourhood, which represent core components 
of the EU foreign policy, are truly facilitated by initiatives that are upheld by the CoR such as the CORLEAP, the ARLEM as well as the EGTCs, allowing for the better fulfillment of the ENP objectives. In fact, the ENP is linearly connected with the EU foreign policy, aiming at bringing closer EU countries and their neighbours in the East ( 6 countries) and the South (10 countries). Both ARLEM and CORLEAP are initiatives that link the EU with the Southern and Eastern partners respectively, thus allowing for regional cooperation and potential policy transferring of EU values and norms. In addition, the EGTC serve as an effective tool for territorial cooperation and platform for exchanging knowledge and expertise, thus facilitating policy diffusion and learning among its members.

- All in all, the analysis has shown that all three political platforms (ARLEM; CORLEAP; EGTC) facilitate subnational cooperative as well as financial type of mobilization. Respectively the role of the regional and local authorities in the implementation of the ENP is considered to be crucial. In a nutshell, sub-state entities have managed to expand their institutional role in new policy fields that have been traditionally monopolized and exercised solely by national authorities. Future research may focus more on specific case studies derived from the three channels of access of SNAs to the ENP and explore in depth certain aspects such as the consequences of mobilization of SNAs in the international arena with regard to the impact on domestic inter-institutional arrangements and the evolvement of the relation of national and subnational authorities of the same state.

Bache, I. (2008). Europeanization and Multilevel Governance. Cohesion Policy in the European Union and Britain. Lanham: Rowman \& Littlefield.

Bache, I., \& Flinders, M. (Eds). (2004). Multi-level Governance. Oxford: Oxford University Press. https://doi. org/10.1093/0199259259.001.0001

Bicchi, F. (2014). "The Politics of Foreign Aid and the European Neighbourhood Policy Post-Arab Spring: 'More for More' or Less of the Same?". Mediterranean Politics , 19 (3), pp. 318-332. https://doi.org/1 $0.1080 / 13629395.2014 .959758$

Börzel, T., \& van Hüllen, V. (2014). “One Voice, One Message, but Conflicting Goals: Cohesiveness and Consistency in the European Neighbourhood Policy". Journal of European Public Policy , 21 (7), pp. 1033-1049. https://doi.org/10.1080/13501763.201 4.912147

Börzel, T., Risse, T., \& Dandashly, A. (2015). "The EU, External Actors, and the Arabellions: Much Ado About (Almost) Nothing". Journal of European Integration , 37 (1), pp. 135-153. https://doi.org/10.1080/ 07036337.2014 .975993

Callanan, M., \& Tatham, M. (2014). "Territorial Interest Representation in the European Union: Actors, Objectives and Strategies". Journal of European Public Policy , 21 (2), pp. 188-210. https://doi.org/10.1080/1 3501763.2013.829579

Commission of the European Communities. (2003). "Paving the Way for a New Neighbourhood Instrument". COM(2003)393 final, Brussels.
Commission of the European Communities. (2004). "Communication from the Commission. European Neighborhood Policy. Strategy Paper". COM (2004)373 final, Brussels.

Committee of the Regions. (2018). EGTC monitoring report 2017. Brussels: European Union.

Committee of the Regions. (2013). Empowering Local Authorities in Partner Countries for Enhanced Governance and More Effective Development Outcomes. CIVEX-V-041, Brussels.

Committee of the Regions. (2016). New Approach to the European Neighbourhood Policy. Report by CASE Poland. Brussels: European Union.

Committee of the Regions. (2012). The EU Funds Available for Local and Regional Authorities from the Southern and Eastern Mediterranean Countries: Information Guide. Brussels: European Union.

De Sousa, L. (2013). “Understanding European Cross-border Cooperation: A Framework for Analysis". Journal of European Integration , 35 (6), pp. 669687. https://doi.org/10.1080/07036337.2012.711827

Edwards, G. (2008). "The Construction of Ambiguity and the Limits of Attraction: Europe and its Neighbourhood Policy". European Integration , 30 (1), pp. 45-62. https://doi.org/10.1080/07036330801959465

Engl, A. (2016). “Bridging Borders Through Institution-Building: The EGTC as a Facilitator of Institutional Integration in Cross-Border Regions". Regional \&

\section{References}


Federal Studies , 26 (2), pp. 143-169. https://doi.org/ $10.1080 / 13597566.2016 .1158164$

European Commission and High Representative of the European Union for Foreign Affairs and Security Policy. (2015a). Implementation of the European Neighbourhood Policy Eastern Partnership Implementation Report. Joint Staff Working Document SWD 76 final, Brussels.

European Commission and High Representative of the European Union for Foreign Affairs and Security Policy. (2015b). Implementation of the EuropeaNeighbourhood Policy. Partnership for Democracy and Shared Prosperity with the Southern Mediterranean Partners Report. Joint Staff Working Document - SWD76 final, Brussels.

Freyburg, T., Lavenex, S., Schimmelfennig, F., Skripka, T., \& Wetzel, A. (2009). "EU Promotion of Democratic Governance in the Neighbourhood". Journal of European Public Policy , 16 (6), pp. 916-934. https:// doi.org/10.1080/13501760903088405

Gänzle, S. (2009). “EU Governance and the European Neighbourhood Policy: A Framework for Analysis”. Europe-Asia Studies , 61 (10), pp. 1715-1734. https:// doi.org/10.1080/09668130903278926

Jeffery, C. (1996a). "Regional Information Offices in Brussels and Multi-Level Governance in the EU: A UK-German Comparison". Regional \& Federal Studies, 6 (2), pp. 183-203. https://doi. org/10.1080/13597569608420975

Hooghe, L. (1995). "Subnational Mobilisation in the European Union”. West European Politics, 18 (3), pp. 175198. https://doi.org/10.1080/01402389508425097

Hooghe, L. (1996). “Introduction: Reconciling EU-Wide Policy and National Diversity". In L. Hooghe (Eds), Cohesion Policy and European Integration: Building Multilevel Governance (pp. 1-26). Oxford: Oxford University Press.

Hooghe, L., \& Marks, G. (1996). “'Europe with Regions': Channels of Regional Representation in the European Union". The Journal of Federalism , 26 (1), pp. 73-91. https://doi.org/10.1093/oxfordjournals. pubjof.a029841

Hooghe, L., \& Marks, G. (2001). Multi-Level Governance and European Integration. Oxford: Rowman \& Littlefield Publishers.

Hooghe, L., \& Marks, G. (2003). “Unraveling the Central State but How? Types of Multilevel Govenrnance". American Political Science Review, 97 (2), pp. 233-43.

Lavenex, S. (2008). “A Governance Perspective on the European Neighbourhood Policy: Integration Beyond Conditionality?". Journal of Europe- an Public Policy , 15 (6), pp. 938-955. https://doi. org/10.1080/13501760802196879

Lavenex, S., \& Schimmelfennig, F. (2011). “EU Democracy Promotion in the Neighbourhood: From Leverage to Governance?". Democratization , 18 (4), pp. 885-909. https://doi.org/10.1080/13510347.2011.584730

Lavenex, S., \& Schimmelfennig, F. (2009). “EU Rules Beyond EU Borders: Theorizing External Governance in European Politics". Journal of European Public Policy , 16 (6), pp. 791-812. https://doi. org/10.1080/13501760903087696

Marks, G. (1992). "Structural Policy in the European Community". In A. Sbragia (Ed.), Euro-politics. Institutions and Policymaking in the "New" European Community (pp.191-225). Washington, DC: The Brookings Institution.

Marks, G., Haesly, R., \& Mbaye, H. (2002). "What Do Subnational Offices Think They Are Doing in Brussels?". Regional \& Federal Studies , 12 (3), pp. 1-23 https://doi.org/10.1080/714004755

Marks, G., Hooghe, L., \& Blank, K. (1996). “European Integration from the 1980s: State-Centric v. Multi-level Governance". Journal of Common Market Studies, 34 (3), pp.341-378. https://doi. org/10.1111/j.1468-5965.1996.tb00577.x

Nadalutti, E. (2013). “Does the ‘European Grouping of Territorial Co-operation' Promote Multi-level Governance within the European Union?". Journal of Common Market Studies , 51 (4), pp. 756-771. https://doi. org/10.1111/jcms.12014

Noutcheva, G. (2015). "Institutional Governance of European Neighbourhood Policy in the Wake of the Arab Spring". Journal of European Integration , 37 (1), pp. 19-36. https://doi.org/10.1080/07036337.2014.975987

Piattoni, S. (2009a). "Multi-level Governance: a Historical and Conceptual Analysis". Journal of European Integration, 31 (2), pp. 163-180. https://doi. org/10.1080/07036330802642755

Sasse, G. (2008). "The European Neighbourhood Policy: Conditionality Revisited for the EU's Eastern Neighbours". Europe-Asia Studies , 60 (2), pp. 295316. https://doi.org/10.1080/09668130701820150

Stephenson, P. (2013). “Twenty Years of Multi-Level Governance: Where Does it Come From? What Is It? Where Is It Going?". Journal of European Public Policy , 20 (6), pp. 817-837. https://doi.org/10.1080/135 01763.2013 .781818

Spinaci, G., \& Vara-Arribas, G. (2009). "The European Grouping of Territorial Cooperation (EGTC): New Spaces and Contracts for European Integration?". ElPASCOPE, 2, pp. 5-13. 
Tatham, M. (2008). “Going Solo: Direct Regional Representation in the European Union". Regional \& Federal Studies , 18 (5), pp. 493-515. https://doi. org/10.1080/13597560802351523

Tatham, M. (2010). “With or without you'? Revisiting Territorial State-Bypassing in EU Interest Representation". Journal of European Public Policy , 17 (1), pp. 76-99. https://doi.org/10.1080/13501760903465082

Tatham, M. (2013). "Paradiplomats Against the State: Explaining Conflict in State and Substate Interest Representation in Brussels". Comparative Political Studies , 46 (1), бo. 63-94. https://doi. org/10.1177/0010414012453031

Tatham, M., \& Thau, M. (2014). “The More the Merrier: Accounting for Regional Paradiplomats in Brussels". European Union Politics , 15 (2), pp. 255-276 https:// doi.org/10.1177/1465116513512539
Tömmel, I. (2013). “The New Neighborhood Policy of the EU: An Appropriate Response to the Arab Spring?". Democracy and Security , 9 (1-2), pp. 19-39. https://doi.org/10.1080/17419166.2012.736306

Xenakis, D. (1999). “From Policy to Regime: Trends in Euro-Mediterranean Governance". Cambridge Review of International Affairs , 13 (1), pp. 254-270 https://doi.org/10.1080/09557579908400289

Zaiotti, R. (2007). "Of Friends and Fences: Europe's Neighbourhood Policy and the 'Gated Community Syndrome' “. European Integration , 29 (2), pp. 143 162. https://doi.org/10.1080/07036330701252581

Zajaczkowski, M. (2017). "Regional cooperation within the Eastern Partnership". European Integration Studies (11), pp. 138-147. https://doi.org/10.5755/ j01.eis.0.11.18428

\section{GIORGIO OIKONOMOU}

Adjunct Lecturer

Aristotle University of Thessaloniki Faculty of author Economic and Political Sciences; School of Political Sciences University Campus, Thessaloniki, Greece

Address

E-mail: giorgio.oikonomou@yahoo.com 